\title{
Adaptation of Electronic Book Publishing Technology by The Publishers in Southeast Nigeria
}

\author{
Godson Emeka Ani*, Chike Ogboh
}

Department of Printing Technology, Institute of Management and Technology, Enugu

\begin{tabular}{l} 
A R T I C L E I N F O \\
\hline Article history: \\
Received: 25 September, 2018 \\
Accepted: 23 November, 2018 \\
Online: 13 December, 2018
\end{tabular}

Keywords:

Electronic publishing

E-book technology

Digital technology

New technology

\begin{abstract}
A B S T R A C T
This paper investigates the electronic book production and distribution practices adopted by the Publishers in Southeast Nigeria because of the global growing interest in writing new book titles in digital form as well as converting paper titles to digital content. To investigate this study, the researcher formulated three research questions to guide the study. A number of relevant literatures were reviewed to establish the gap anchored on the Technological Determinism Theory. Descriptive Survey design and In-depth interviews were used to elicit data for the study. Fifteen publishing firms were randomly selected from Enugu (Enugu State) and Onitsha (Anambra States). Data from the survey were analyzed using the Statistical Package for Social Sciences (SPSS). The key findings of the study include that: the rate of adaptation of e-book technology by educational publishers in the southeast Nigeria is relatively low. However, books are now distributed and sold in digital forms as online books and print on demand titles by publishers in southeast Nigeria through the Internet; Lack of adequate regulations for the protection of intellectual resources, high cost of digital equipment, incessant power failure and high cost of using alternative power supply for e-book distribution, are some of the challenges undermining the adaptation of ebook publishing technology in Southeast Nigeria. It was recommended that the government should provide an enabling environment through dependable infrastructure for the promotion, distribution and marketing of e-books in the Southeast Nigeria. The Book Publishers Association of Nigeria should also make commitment to the development of indigenous book market.
\end{abstract}

\section{Introduction}

The advances in Information Communication Technologies have structurally changed the way books are produced, distributed and sold. Book publishers all over the world are diversifying into electronic publishing - digital publication of e-book, digital magazines, and the development of digital libraries and catalogues. Strongly associated with electronic publishing are many non-network electronic publications such as encyclopedias on CD and DVD as well as technical and reference publications relied on by mobile users. The entry of core technology companies into the publishing space and the introduction of portable electronic reading devices have made digital books gain wider interest. Digital technology has changed the face of all media, including print. In order to survive, all parties involved must adapt and focus on the consumers' changing needs [1]. Publishers in Nigeria who fail to digitalize their future/current book titles may lose out in the emerging publishing market [2].

${ }^{*}$ Corresponding Author: Godson Emeka Ani, Email: godsonani@imt.edu.ng www.astesj.com

https://dx.doi.org/10.25046/aj030650
The print products (print media) can be used by the customers directly (the information is available on paper), whereas electronic media (e.g. CD-ROM or network as a medium) requires special equipment for its visualization (monitor, computer, connection to the network).

Electronic books (e-books) are book titles that are available online. They can be read as e-mail, retrieved by a portable electronic reading device or as a file and can be downloaded on a computer [3]. The most popular method of getting an e-book is to purchase a downloaded file of e-Book from a website, such as Barnes and Noble or through on-line bookshops, such as Amazon.com. Electronic book publishing is available in Nigeria through Bookstores, Amazon, Lulu, Smashword, Createspace, Okadabooks, Nook and African Books Collective (ABC) for the print-on-demand titles.

Roger fidler asserts that "When new forms of communication media emerge, the older forms usually do not die - they 
continue to evolve and adapt. In this way, the different media compete for the public's attention and jockey for positions of dominance but no media has yet disappeared. It is obvious that each medium contributes to the development of its successors"[4].

E-book publishing is enabling new authors to release books that would be unlikely to be profitable for traditional publishers. It makes a wider range of books available, including books that would not have been available in book retailers' shop due to insufficient demand. This technology also responds quickly to changing market demand, reduces production and distribution costs and gets more books to readers faster than the current publishing business model. This fundamental shift in the media scope is driving on how consumers engage with brands and how marketers have to go where the customers are, in order to communicate effectively and efficiently [1]. There are indications that electronic publishing is becoming a major mode of publishing in many countries [5].

This paper investigates the electronic book production and distribution practices adopted by the Publishers in Southeast Nigeria because of the global growing interest in writing new book titles in digital form as well as converting paper titles to digital content.

\subsection{Problem Statement}

The emergence of new communication technology shrinks the world into a global village and made authors to market their digital contents directly to their consumers. The business of book publishing has advanced from hand setting of movable metal type to Linotype setting, Monotype setting, Lithographic offset printing, Word processing, Desktop publishing, online books and now portable electronic books [2]. But today, print channel is limited to a certain field of applications.

The books being produced by the indigenous publishers could not compare with the established Publishing Houses abroad and many publishers are no longer in the business. Publishing houses have closed down because there was no capital to continue, while the rest have been struggling to survive [6]. It has not been easy for many indigenous publishers in recent years.

The computer literacy level in the society is low and majority of the populace do not find any comfort in reading from a computer screen. The high cost of personal computer in the country has also caused a considerable low computer ownership density and limited access to Internet facilities.

It is really worrisome to imagine how the publishers in the Southeast Nigeria could survive the changing global publishing business if they fail to adapt e-book technology now. The need to find answers to this worry is what informed this study.

\subsection{Justification}

It is expected that this study will help the publishers to integrate electronic book (e-book) publishing technology in their present and future book titles in order to be relevant in the emerging publishing market. It is also expected that the rapidity in the publishing industry will create opportunities for the publishers in the global competition.

\subsection{Objectives}

The general objective is to assess the adaptation of electronic book publishing technology by the publishers in Southeast Nigeria.

The specific objectives are as listed below:

- To determine the extent in which e-book technology is adopted by educational publishers in Southeast, Nigeria.

- To examine the benefits accrued by educational publishers who adopt e-book technology in Southeast, Nigeria.

- To ascertain the challenges posed by the adaptation of e-book technology in the publishing business in Southeast, Nigeria.

\subsection{Research Questions}

- To what extent has Digital Book Technology been adopted by Educational Publishers in Southeast Nigeria?

- What are the benefits of the adaptation of digital book technology to educational publishers in Southeast Nigeria?

- What are the challenges posed by the adaptation of e-book technology in the publishing business in Southeast Nigeria?

\subsection{Scope of the Study}

The scope of this study was narrowed down to the Educational Publishers in Onitsha, Anambra State and Enugu, Enugu State, both in Southeast zone Nigeria. Electronic book publishing technology as operationalized in this study refers to books distributed by any form of electronic device, including books on CD-ROM, Books in Cassette, Paper books with CD-ROM, Audio CD Books and Print-on-Demand.

\subsection{Limitations of the Study}

The limitations of this study include the poor attitude of some of the educational publishers to research work. They were reluctant to accept appointment for oral interviews but would rather prefer to complete the copy of questionnaire.

The research also observed that a reasonable number of the Educational Publishers in the Southeast Nigeria print and market only the Traditional Hardcopy Book Titles, unlike what happens in Lagos and Ibadan (Southwest Nigeria).

\section{Literature Review}

Technology plays a dominant role in changing almost all facets of the publishing industry, from the writing to the distribution of books to final consumers. Even the process of distributing books to the final consumers has been made easier with electronic mail, inventory management programs and other tools. According to 
former Times Mirror group Vice-President, Jerome Rubin, whereas Gutenberg's moveable type enabled such mass distribution of identical copies upon its implementation in the fifteenth century, the twentieth century's "electronic technologies allow the creation of infinite variations" [7].

Digital communication technologies and processes for designing and producing information as print media or electronic media are penetrating the market. This means that the production processes for both groups of media are closely interconnected by a common basis, the pre-media production section. The pre-media area prepares the content and produces a digital document that may, to a large extent, be used in both sectors of production; "cross-media publishing" has become possible and is in place in the printing, publishing and communication industries [8].

Basically, new technology has enabled the consumer to assume some of the traditional publisher's role in the choice and format of information, leaving the consumer with more control [7]. The Transfer of Information, documents and content via electronic media (CD-ROM or Internet) creates a varied array of interesting and useful applications. Electronic media can provide innovative alternatives to print media. In contrast to the simple, flexible handling of the common book, however, digital playback of reading material can be relatively complicated and awkward [8]. Suitable software tools and interactive user interfaces will enable the text passage to be marked with circling, highlighting or page marking. These are measures that will improve the acceptance of electronic books. Several websites such as www.fictionwise.com, www.gutenberg.org and www.memoware.com, offer e-books specifically for PDAs and cell phones. Existing models such as the Rocket e-book (NuvoMedia), Softbook (Softbook Press) and EB Study Model (Everybook) have made it easier for readers to peruse an e-book. Additionally, by mastering a few key functions, the user can operate this e-book in a variety of places, thus making network-independent reading simple.

Convergence is altering almost all aspects of the book industry. Most obviously, the Internet is changing the way books are distributed and sold. But this new technology, in the form of epublishing, the publication of books initially or exclusively online, offers a new way for writers' ideas to be published. Epublishing can take the form of d-books and print on demand (POD) [9]. Digital books content could also be selected and downloaded from the catalogue of books in Publishers' Database and instantly printed as Print-on-Demand (POD) titles in a bookstore that has the appropriate technology. The printed and bound copies are produced on demand with the possibility of buying chapter-by-chapter. Examples of POD Publishers are Xlibris, Authors House, and Toby Press.

E-books have potential in enhancing distance education. In particular, e-books are able to enhance the interaction between educators and students when dealing with teaching and learning materials [3]. Computers and computerized editorial systems are now used to write texts, process images and produce books.

The Internet and World Wide Web (www) are facilitating the publishing of books in the areas of typesetting, layout and editing, on-line distribution, on-line ordering, marketing, advertising, pricing, payments and hiring [2, 10, 11, 12]. Most digital publishers now provide a full range of services such as copy editing, online publishing, securing or commissioning artwork, jacket design, promotion, and in some cases, even hard copy distribution to brick-and-mortar book stores, based on a variable royalty or fee arrangement.

The content of e-book can be delivered to multiple platforms and operating systems to reach broad audience at a reduced cost. The use of CD-ROM and Internet publishing has circumvented the constraints of paper to a reasonable extent if extensively adopted.

The advantages of e-publishing for readers are in time and money. D-books are down loaded at a very low cost as compared with the cost of the hardcopy and an electronic bookstore never closes. No matter what time of the day or night, readers can download their textbooks and begin reading immediately. Print-on-Demand (POD) reduces production and distribution cost, by getting books faster and cheaper to readers, than the current publishing business model.

The physical form of books is changing using this new technology - many of today's books are no longer composed of paper pages snuck between two covers [13]. The Internet is changing the way books are The Internet made it possible for an author to write a book, puts it on a website and offers it for sale, without the aid of a traditional publisher or retailer. An author could as well place a manuscript on a website run by a company that collects and distributes e-books. Distributed and sold

The challenges of book distribution can be remedied by making books more accessible through alternative publishing models; electronic publishing and through print-on-demand technologies [2]. He concluded by saying that e-publishing in Nigeria is simply a novelty and the appropriate reading habit a mirage. Digital content is ever-harder to control. In one sense, everything is Openaccess. Even though some publishers are fighting the pirated titles with law suits and authentication technology, others embrace open access [14].

Digital books are now distributed over several delivery channels, primarily a combination of print and Internet. The Internet helps larger media organisation to have more publication channels. It has opened new frontiers for expansion, taste and distribution of print information thus, sustaining industrialization in Nigeria. Books could also be made more accessible through co-publishing; a model that allows publishers from different parts of the world to publish a book jointly so that a title is made available to different markets by publishers in the respective territories [15].

Some authors now take advantage of e-publishing to publish their e-book on the Internet by themselves [2]. Authors who publish in 
their own websites keep 100 percent of the income while authors who distribute their works through an established e-publisher. Additionally, he said that they usually get royalties of 40 percent to 70 percent, compared to the 5 percent to 10 percent offered by traditional publishers.

Generally underdeveloped market, a weak developed reading culture, lack of distribution hubs such as commercial outlets and short print runs are part of the challenges facing book publishers today [16]. The publication of e-book is technology driven, cheaper, and there is no distribution or warehousing cost.

\subsection{Theoretical Framework}

The study was anchored on Technological Determinism Theory whereby technology is viewed as a driver of social change. It explains that when new systems of technology are developed, society will immediately change and adapts to that technology. Hence, "the medium is the message".

Media do not only extend our reach and increase our efficiency, they act as filter to organize and interpret our social existence [17]. The message that is produced on the traditional print media on paper formats is unique in many ways with the same message that is produced on the electronic board of a computer. The innovation of electronic book publishing technology opens a new frontier for production, expansion, taste and distribution of books in Nigeria.

A change in technology has a multiplier effect on other factors. Hence, the phrase, "we shape our tools and they in turn shape us" explains how one aspect of change affects all others. The digitalization and convergence of computer technology have greatly influenced the way information is produced and disseminated in the Book Publishing Industry. A consumer that obtained gratification in reading various book publications online, as against reading only the traditional paper books will not hesitate to adopt the e-books. Similarly, a publisher is likely to be interested in the direction of the market force and the profit that will be realized from every venture. He is likely to adopt the new technology as a result of the market shift to satisfy customers' demand and taste. The electronic book technology (shaping of our tools) compels educational publishers to adjust and reposition themselves in order to use the modern tools (they in turn shape $u s)$.

The application of Technological Determinism Theory in this study is justified since the change in technology made book publishers to acquire more sophisticated skills that help print information to appreciate in value.

\section{Methodology}

The survey research method and semi structured interviews were used to gather data from practicing publishers in Enugu, Enugu State and Onitsha in Anambra State, Nigeria, where about 75 percent of all the publishing houses in the Southeast zone, Nigeria are based.
Fifteen (15) copies of questionnaire were distributed to practicing educational book publishers in Onitsha, Anambra State, and Enugu in Enugu State, Nigeria. The questionnaire consists of thirteen (13) close-ended questions. Fifteen (15) copies of questionnaire were successfully completed; giving a return rate of 100 percent. In order to validate the data from the survey, semi structured interviews were conducted with two publishers based in Enugu and Onitsha respectively. Notes from the in-depth interviews were transcribed and analyzed using hermeneutic interpretation. Data from the survey was analyzed using the Statistical Package for Social Sciences (SPSS).

The following publishers were randomly selected from the list of printing and publishing companies in Nigeria [18] and Enugu state [19]:

(i) DeRafelo Ltd, Enugu; (ii) Fourth Dimension Publishing Company Ltd, Enugu; (iii) Rocana Enugu; (iv) New Generation Educare Ltd, Enugu; (v) Kongrat Press, Enugu; (vi) Executive Press Resources Ltd, Enugu; (vii) Jibalo Publishers, Enugu; (viii) Rhyce Kerex Publishers, Enugu; (ix) Keny and Brothers Ventures, Enugu; (x) Dulacs Publishers, Enugu; (xi) K.C.Graphics and Design, Enugu; (xii) Brand Wise Advertising/Publishing Ltd, Enugu; (xiii) Pacific Publishers, Onitsha; (xiv) University Publishing Company Ltd, Onitsha; (xv)Diamond-Pen Publishing Company Ltd, Onitsha.

\subsection{Data Presentation}

The data in table 1 shows that 3 publishers or 20 percent of their sampled publishers engage in book publishing only while 12 publishers or 80 percent combine printing and publishing. The above data shows that the majority of the respondents were educational book publishers.

Table 1: Scope of the Publisher

\begin{tabular}{|l|l|l|l|}
\hline S/N & Specialty & Respondents/Publishers & Percentage \\
\hline (a) & Publishing only & 3 & 20 \\
(b) & Printing \& Publishing & 12 & 80 \\
\hline
\end{tabular}

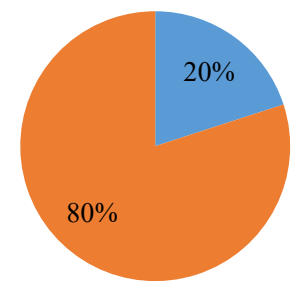

- Publishing only

— Printing \& Publishing

Table 2 shows that 7 publishers, representing 47 percent of the sampled book publisher either produce and market their traditional books with CD-ROM, 11 publishers or 73 percent have digitized their books and market them online as print-on-demand 
titles 7 publishers or 47 percent market their books as CD-ROM only, while 2 publishers, representing 13 percent of the respondents, market their e-books in Cassette and CD. The analyzed data above indicated that majority of the publishers adapt the Print-on-demand technology for e-book publishing.

Table 2: Extent of adoption of digital book technology (available variety)

\begin{tabular}{|ll|l|l|l|l|}
\hline Format & & Frequency & Percent & $\begin{array}{l}\text { Valid } \\
\text { Percent }\end{array}$ & $\begin{array}{l}\text { Cumulativ } \\
\text { e Percent }\end{array}$ \\
\hline Valid & Audio CD Books & 1 & 20.0 & 20.0 & 20.0 \\
& Books in Cassette & 1 & 20.0 & 20.0 & 40.0 \\
& Books in CD-ROM & 1 & 20.0 & 20.0 & 60.0 \\
Paper Books with CD- & 1 & 20.0 & 20.0 & 80.0 \\
ROM & 1 & 20.0 & 20.0 & 100.0 \\
Prints-on-demand titles & 1 & 100.0 & 100.0 & \\
Total & 5 & &
\end{tabular}

The data in table 3 above shows that all the sampled publishers agree that new technologies have brought impressive improvement in the quality of their colour design, while 14 publishers representing 93 percent indicated that new technologies also improved the quality of book content. 10 publishers, representing 67 percent admitted an improvement in inside illustrations, 8 publishers or 53 percent admitted improvement in layout, 7 publishers or 47 percent indicated improvement on cover lamination, binding and finishing. The analyzed data indicated that the quality of the cover design and content of books published today are better because of the adaptation of digital technology.

Table 3: Areas of improved quality on output due to newly adopted technology

\begin{tabular}{|ll|l|l|l|l|}
\hline Format & & Frequency & Percent & $\begin{array}{l}\text { Valid } \\
\text { Percent }\end{array}$ & $\begin{array}{l}\text { Cumulativ } \\
\text { e Percent }\end{array}$ \\
\hline Valid & Binding and Finishing & 1 & 16.7 & 16.7 & 16.7 \\
& Cover Design & 1 & 16.7 & 16.7 & 33.3 \\
& Cover Lamination & 1 & 16.7 & 16.7 & 50.0 \\
& Inside Illustrations & 1 & 16.7 & 16.7 & 66.7 \\
& Layout & 1 & 16.7 & 16.7 & 83.3 \\
Quality of Book Content & 1 & 16.7 & 16.7 & 100.0 \\
Total & 6 & 100.0 & 100.0 & \\
\hline
\end{tabular}

\begin{tabular}{|l|l|l|}
\hline \multicolumn{2}{|c|}{ Statistics } \\
\hline \multicolumn{2}{|c|}{ Percentage } \\
\hline N & Valid & 6 \\
\cline { 2 - 3 } & Missing & 0 \\
\hline Mean & 67.83 \\
\hline Median & 60.00 \\
\hline Std. Deviation & 23.481 \\
\hline Variance & 551.367 \\
\hline
\end{tabular}

The data in table 4 above shows that 13 publishers, representing 87 percent of the entire population admit that new technologies improved the prepress in the areas of reformatting, editing and easy input of information. 11 publishers or 73 percent admitted that there is improvement in redesigning and printing, while 9 publishers or 60 percent and 8 publishers or 53 percent identified improvement in the rewriting and spell-checking of typeset matters. The analyzed data indicated that electronic editing has made it easy for publishers to input, reformat, edit, reformat and print books.

Table 4: Aspect of improvement in prepress due to the adaptation of Digital Technology

\begin{tabular}{|l|l|l|l|l|l|}
\hline & & Frequency & Percent & Valid Percent & $\begin{array}{l}\text { Cumulative } \\
\text { Percent }\end{array}$ \\
\hline Valid & Easy to Input & 1 & 20.0 & 20.0 & 20.0 \\
\cline { 2 - 6 } & Redesign \& Print & 1 & 20.0 & 20.0 & 40.0 \\
\cline { 2 - 6 } & Reform \& Edit & 1 & 20.0 & 20.0 & 60.0 \\
\cline { 2 - 6 } & Rewrite & 1 & 20.0 & 20.0 & 80.0 \\
\cline { 2 - 6 } & Spell-check & 1 & 20.0 & 20.0 & 100.0 \\
\cline { 2 - 6 } & Total & 5 & 100.0 & 100.0 & \\
\hline
\end{tabular}

\begin{tabular}{|l|l|l|}
\hline \multicolumn{2}{|c|}{ Statistics } \\
\hline \multirow{2}{|c|}{ Percentage } \\
\hline Valid & 5 \\
\cline { 2 - 3 } & Missing & 0 \\
\hline Mean & 70.60 \\
\hline Median & 73.00 \\
\hline Std. Deviation & 14.011 \\
\hline Variance & 196.300 \\
\hline
\end{tabular}

Table 5: Skill development strategies adopted for e-book publishing.

\begin{tabular}{|c|c|c|c|c|c|}
\hline \multicolumn{6}{|c|}{ Training } \\
\hline & & Frequency & Percent & $\begin{array}{l}\text { Valid } \\
\text { Percent }\end{array}$ & $\begin{array}{l}\text { Cumulative } \\
\text { Percent }\end{array}$ \\
\hline \multirow[t]{5}{*}{ Valid } & & 2 & 40.0 & 40.0 & 40.0 \\
\hline & In-service Course & 1 & 20.0 & 20.0 & 60.0 \\
\hline & On-the-Job Training & 1 & 20.0 & 20.0 & 80.0 \\
\hline & Short-service Course & 1 & 20.0 & 20.0 & 100.0 \\
\hline & Total & 5 & 100.0 & 100.0 & \\
\hline
\end{tabular}

Table 5 shows that 10 publishers, representing 67 percent train staff on digital publishing through the in-service-course, 11 publishers, representing 73 percent train staff on-the-job, while 3 publishers, representing 20 percent train the staff through the short-service-course. The analyzed data indicated that the publishers adopted "In-service-Training" strategies to embrace ebook technology.

Table 6 shows that 15 respondents, representing 100 percent are of the opinion that Incessant power failure and fluctuation of electricity is a factor undermining the adoption of e-book technology in the Southeast Nigeria, while 12 respondents, representing 80 percent of the sampled publishers indicated that cyber copyright and piracy are militating against the flourishing of electronic commerce in Southeast Nigeria. 11 respondents, representing 73 percent opined that they encountered the challenge of learning a new skill (computer technology) in the 
adaptation of e-book publishing technology. Eight (8) respondents, representing 53 percent admitted that the adaptation of new technologies has rendered some publishing equipment redundant, while 6 publishers agreed that staff were retrenched and most of the publishing organizational settings were restructured as a result of the adaptation of e-book technologies. The analyzed data indicated that incessant power failure, cyber copyright and piracy constitute a major obstacle to the adaptation of e-book technology.

Table 6: Challenges encountered in adaptation of e-book publishing

\begin{tabular}{|ll|l|l|l|l|}
\hline & Frequency & Percent & $\begin{array}{l}\text { Valid } \\
\text { Percent }\end{array}$ & $\begin{array}{l}\text { Cumulativ } \\
\text { e Percent }\end{array}$ \\
\hline Valid & $\begin{array}{l}\text { Cyber Copyright and } \\
\text { Piracy } \\
\text { Difficulty of Learning } \\
\text { New Skill }\end{array}$ & 1 & 16.7 & 16.7 & 16.7 \\
$\begin{array}{l}\text { Fluctuation of } \\
\text { Electricity } \\
\text { Redundant Publishing } \\
\text { Equipment } \\
\text { Restructured } \\
\text { Organizational Setting } \\
\text { Retrenchment of Staff } \\
\text { Total }\end{array}$ & 1 & 1 & 16.7 & 16.7 & 33.3 \\
\hline
\end{tabular}

\begin{tabular}{|c|c|c|}
\hline \multicolumn{3}{|c|}{$\begin{array}{l}\text { Statistics } \\
\text { Percentage }\end{array}$} \\
\hline \multirow[t]{2}{*}{$\mathrm{N}$} & Valid & 6 \\
\hline & Missing & 0 \\
\hline \multicolumn{2}{|c|}{ Mean } & 64.33 \\
\hline \multicolumn{2}{|c|}{ Median } & 63.00 \\
\hline \multicolumn{2}{|c|}{ Std. Deviation } & 24.105 \\
\hline \multicolumn{2}{|c|}{ Variance } & 581.067 \\
\hline
\end{tabular}

\section{Discussions/ Analysis:}

\subsection{Research Question One: To what extent has Digital Book Technology been adopted by Educational Publishers in Southeast Nigeria?}

The survey shows that educational publishers in Southeast Nigeria adopted more of the print-on-demand titles $(73 \%)$ than other variety of e-book products on Table 3, and closely followed by the adoption of CD-ROM attachment to the traditional book $(47 \%)$.

\subsection{Research Question Two: What are the benefits of the adaptation of digital book technology to educational publishers in Southeast Nigeria?}

The adoption of digital books has significantly contributed to the improvement in the quality of published books in the areas of cover design (100\%), book content (93\%), inside illustrations $(67 \%)$, and layout $(53 \%)$, as indicated in table 4 .
The adoption of new communication technologies enabled publishers in Southeast to reap the benefits of digital book reformat and editing (87\%), ease of input (87\%), redesign and printing $(73 \%)$, as indicated on table five. The conduit that is often used for e-book publishing in the Southeast is e-mail address $(87 \%)$, while conduits such as website and other internet facilities or access are not yet prevalent (table 6). The survey also shows that the marketing and distribution of e-book is chiefly through "e-publishing partnership (73\%). In order to ensure the preparedness of the local workforce for the shift in technology, the type of the training adopted for the purpose of e-book technology was investigated. The survey shows that the most prominent skill development strategies adopted for e-book publishing in the Southeast is "on-the-job training (73\%) and inservice course $(67 \%)$.

\subsection{Research Question Three: What are the Challenges posed by the adaptation of e-book technology in the publishing business in Southeast Nigeria?}

The survey shows that there is no security for the protection of intellectual property that is in digital form such as e-book $(80 \%)$, and copies are distributed over the internet or via pirated CDROMs at a very low cost. The survey collaborated the opinion of Mr. James Opara's view that the rate of piracy is discouraging a lot of publishers from publishing their e-books in the southeast Nigeria, since piracy has adverse effect on job turnover. The incessant power failure/fluctuation of electricity is a major hindrance to the adaptation of e-book technology in the Southeast Nigeria (100\%). The e-book technology involves the learning of new skill (computer technology), and some of the publishers sampled indicated that it constituted a great challenge (73\%). Some analogue publishing equipment and staff were rendered redundant due to the adaptation of e-book technology by educational publishers (table 9).

\section{Conclusion and Recommendations}

\subsection{Conclusion}

The study shows, in empirical term, that the rate of adaptation of e-book technology by educational publishers in the southeast Nigeria is relatively low. However, books are now distributed and sold in digital forms as online books and print on demand titles by publishers in southeast Nigeria through the Internet. E-book technology has greatly improved book publishing in the area of pre-press; formatting, layout, editing, spell checking and design.

This agrees with the suggestion [1] that this fundamental shift in the media scope is driving on how consumers engage with brands and how marketers have to go where the customers are, in order to communicate effectively and efficiently. It also agrees with the argument [20] that the book publishing industry will be profoundly affected by the shift to digital. We further discovered that educational publishers who adopted e-book technology in the southeast Nigeria used the e-publishing technology to release books that consumers would not have been able to find in standard 
retailers' bookshops due to insufficient demand for the traditional 'print-run'.

This attribute was characterized by underdeveloped market and a weak developed reading culture [16]. Accordingly, some authors now take advantage of e-book to publish their work on the Internet. This innovation has empirically opened new frontier for production and expansion via distribution of books in Nigeria.

E-publishing has responded to the changing market demand by making a wide range of books available and enabling the traditional book publishers digitize their current book titles. However, Lack of adequate regulations for the protection of intellectual resources, high cost of digital equipment, incessant power failure and high cost of using alternative power supply for e-book distribution, are some of the challenges undermining the adaptation of e-book publishing technology in Southeast Nigeria.

Despite these challenges, e-book distribution and sales are now accessible through alternative publishing model: electronic publishing and through print-on-demand technologies [2]. Generally, the adaptation of e-book technology is gaining reasonable ground among educational publishers in Southeast Nigeria.

\subsection{Recommendations}

The government should provide an enabling environment through dependable infrastructure for the publication and marketing of ebooks in the Southeast Nigeria.

Efforts must be intensified to ensure that the publishing houses in Nigeria are comparable with their counterparts in developed countries in order to avoid print flight. Indigenous book publishers should go beyond the appreciation of imported printed items and strategies on the possibility of replicating the same in Southeast Nigeria.

Policy makers should put relevant law in place that will discourage pirates from exploiting the intellectual resources of electronic book publishers.

Institutions and corporate organizations should be encouraged to have their e-libraries and e-learning platforms so as to encourage e-book technology and electronic book consumers to be able to read at their own pace anytime and anywhere.

There should be relevant regulatory bodies in e-publishing and traditional book publishing business that will monitor the standard of published books and ensure that it meets the approved standard. This body should observe ethics, rules and regulations for engaging in the publishing industry.

The Federal and State Governments should give financial assistance to educational Book publishing industry, to enable them to transit from the traditional book publishing into electronic book publishing. They should also enhance power generation to the industry.
The Book Publishers Association of Nigeria should make serious commitment to develop the indigenous book market.

\section{Acknowledgements}

The authors gratefully acknowledge the Tertiary Education Trust Fund (TETFund), Nigeria for the funding of the research project from which this paper is drawn. The views expressed in the paper are those of the authors, and neither the TETFund nor the authors' institutional affiliation (IMT, Enugu) bears responsibility for them.

\section{References}

[1] G. Stamp, T. Hodson, The need for transformation within the UK printing sector. London: Dotgain.org white paper, 2010.

[2] E. Ifeduba, "Digital publishing in Nigeria: evidence of adoption: evidence of adoption and implications for sustainable development in journal of research, in journal of research in national development”. Vol.8, No.1 pp.1-8, June, 2010.

[3] N. Shiratuddin, M. Landon, F. Gibb, S. Hassan, "E-book technology and its potential- applications in distance education", Texas Digital Library, Vol. 3 No 4, 2003.

[4] S. Biagi, Media Impact: An Introduction to Mass Media, Canada: Thomson Wadsworth, 2003.

[5] M. Tiamiyu, Prospects of Nigerian Book Publishing in the Elecronic Age in Adesanoye and Ojeniyi (eds), Issues in Book Publishing in Nigeria, Ibadan: Heinemann Educational Books. pp.143-157, 2005.

[6] A. Alhassan, Our Challenges, By Indigenous Publishers, Daily Trust, Saturday, April 14, 2013, 2013.

[7] H. Tetkeh, "Evolution of the book publishing Industry: structural changes and strategic implication in journal of management history" vol.4 No.2, pp104 - 123, 1998 .

[8] H. Kipphen, Hardbook of print media, Heidelberg Germany. SPIN: 10764981, 2001

[9] S. J. Baran, Introduction to Mass Communication: Media Literacy and Culture: Fifth Edition. Boston: McGraw-Hill, 2009.

[10] G. O. Abegunde, Quality Book Production in Nigeria, in Adejuwon (ed.) Quality Book Production, Ibadan: Codat publications, 2003.

[11] C. O. Adejuwon, Quality in Book production in Adejuwon (ed.) Quality Book production. Ibadan: Codat Publications, 2003.

[12] J. J. Iwu, Problems of the book publishing industry in Nigeria: the Onibonje publishers experience after 50 years. PNLA quarterly, 75 (3). Pp. 105-111, 2011.

[13] S. J. Baran, Introduction to Mass Communication: Media Literacy and Culture: Second Edition. Boston: McGraw-Hill, 2002.

[14] R. Schonfeld, Book Publishing: University Presses Adapt, in Springer Nature (Online): Macmillan Publishers Limited, 2017.

[15] A. Veglis, "Cross-media publishing by U.S. Newspapers, in Journal of Electronic Publishing”. Vol.10, Issue 2, 2007. Doi: http://dx.doi.org/10.3998/3336451.0010.211

[16] S. Ngbeni, Scholarly publishing: The Challenges Facing the African University Press, The Netherlands. African Studies Centre, 2012

[17] H. E. Ikpe, S. S. Ibekwe, "The Print Media and the Consumer in the Cyber", 2007.

[18] "Nigeria Printing and Publishing Companies", Finelib.com

[19] "List of Printing and Publishing Companies in Enugu State", Galleria Media Limited.

[20] J. R. Dominick, "The dynamics of mass communication media in the digital age", $7^{\text {th }}$ Edition. New York, McGraw-Hill, 2002. 